\title{
Genotypic identification of some lactic acid bacteria by amplified fragment length polymorphism analysis and investigation of their potential usage as starter culture combinations in Beyaz cheese manufacture
}

\author{
A. G. Karahan, ${ }^{* 1}$ G. Başyiğit Kılıç,† A. Kart, ${ }^{*}$ H. Şanlıdere Aloğlu, ${ }^{*}$ Z. Öner, ${ }^{*}$ S. Aydemir,ł O. Erkuş,§ \\ and S. Harsa§ \\ *Süleyman Demirel University, Faculty of Engineering and Architecture, Department of Food Engineering, 32260 Isparta, Turkey \\ †Mehmet Akif Ersoy University, Higher School of Vocational Education, Department of Dairy Products, 15100 Burdur, Turkey \\ †ENKA Dairy Factory, 42150 Konya, Turkey \\ §ìzmir High Technology Institute, Faculty of Chemistry, Department of Food Engineering, 35430 İzmir, Turkey
}

\section{ABSTRACT}

In this study, 2 different starter culture combinations were prepared for cheesemaking. Starter culture combinations were formed from 8 strains of lactic acid bacteria. They were identified as Lactococcus lactis ssp. lactis (2 strains), Lactobacillus plantarum (5 strains), and Lactobacillus paraplantarum (1 strain) by amplified fragment length polymorphism analysis. The effects of these combinations on the physicochemical and microbiological properties of Beyaz cheeses were investigated. These cheeses were compared with Beyaz cheeses that were produced with a commercial starter culture containing Lc. lactis ssp. lactis and Lc. lactis ssp. cremoris as control. All cheeses were ripened in brine at $4^{\circ} \mathrm{C}$ for $90 \mathrm{~d}$. Dry matter, fat in dry matter, titratable acidity, $\mathrm{pH}$, salt in dry matter, total N, watersoluble N, and ripening index were determined. Sodium dodecyl sulfate-PAGE patterns of cheeses showed that $\alpha_{S}$-casein and $\beta$-casein degraded slightly during the ripening period. Lactic acid bacteria, total mesophilic aerobic bacteria, yeast, molds, and coliforms were also counted. All analyses were repeated twice during d 7, 30, 60, and 90. The starter culture combinations were found to be significantly different from the control group in $\mathrm{pH}$, salt content, and lactobacilli, lactococci, and total mesophilic aerobic bacteria counts, whereas the cheeses were similar in fat, dry matter content, and coliform, yeast, and mold counts. The sensory analysis of cheeses indicated that textural properties of control cheeses presented somewhat lower scores than those of the test groups. The panelists preferred the tastes of treatment cheeses, whereas cheeses with starter culture combinations and control cheeses had similar scores for appearance and flavor. These results indicated that

Received October 10, 2008.

Accepted September 8, 2009.

${ }^{1}$ Corresponding author: aynur@sdu.edu.tr both starter culture combinations are suitable for Beyaz cheese production.

Key words: starter culture, lactic acid bacteria, amplified fragment length polymorphism analysis, Beyaz cheese

\section{INTRODUCTION}

White-brined cheeses (also known as white-pickled cheeses) are the most popular varieties of cheeses manufactured in the Northeast Mediterranean area and the Balkans. Such cheeses include Beyaz Peynir (Turkey), Beli Sir U Kriskama (Yugoslavia), Bjalo Salamureno Sirene (Bulgaria), Feta (Greece), Teleme (Romania), Domiati (Egypt), and Halloumi (Cyprus). Turkish Beyaz cheese is a soft or semi-hard cheese that is manufactured from raw sheep's milk, raw cow's milk, or a mixture of the two and is then ripened in brine. Salt content is the main difference in the cheese varieties produced in Northern European countries. Traditionally, Beyaz cheese is manufactured from raw milk in small dairy plants or on farms and at private houses (Bintsis and Papademas, 2002; Hayaloğlu et al., 2002; Oner et al., 2006a). Starter culture is not added to the cheese; therefore, natural lactic acid microflora predominate over the other microbial groups during ripening and may regulate the ripening characteristics (Öner et al., 2006a). The produced cheeses are consumed after a 3 -mo ripening period. This ripening period is also necessary for pathogen inhibition.

Because the demand for Beyaz cheese has rapidly increased during the past 3 decades, Beyaz cheese is now produced in large dairies. In industrial-scale production, pasteurization of raw milk is essential for cheesemaking. However, the pasteurization process destroys pathogens as well as the indigenous flora of raw milk. In cheeses that are made from pasteurized milk, the formation of flavor components delays or develops at a low level (Yllsay, 2000). Although several imported 
commercial starter cultures have been commonly used for the manufacture of Beyaz cheese and they contain subspecies of Lactococcus lactis, a combination of lactococci, and even yogurt cultures (Dağdemir et al., 2003; Dağdemir and Özdemir, 2008; Başyiğit Kılıç et al., 2009), presently there is still no commercial starter culture production in Turkey. In plants using starter cultures, there are problems with culture usage. The main problem is that only a few studies have investigated the suitability of imported cultures to Turkish Beyaz cheese. In such cases it is unavoidable to have cheeses of different quality on the market. Cheeses with these starter cultures do not satisfy the expectations of the consumer because traditional Beyaz cheese contains a wide variety of lactic acid bacteria (Kayagil, 2006). For this reason, the composition of the lactic bacterial flora of Turkish Beyaz cheese was investigated in several research studies. In a study conducted on Beyaz cheese, Lc. lactis ssp. lactis and enterococci (Enterococcus faecalis and Enterococcus faecium) were the predominant species at the beginning of ripening, whereas Lactobacillus casei, Lactobacillus plantarum, Lactobacillus fermentum, Lactobacillus brevis, Leuconostoc lactis, and Leuconostoc mesenteroides ssp. dextranicum were seldom present. The presence of lactococci declined during ripening whereas Lactobacillus species such as $L$. casei and L. plantarum became predominant (Karakuş et al., 1992; Öner et al., 2006a; Dağdemir and Özdemir, 2008). Tzanetakis and Litopoulou-Tzanetaki (1992) also reported that lactobacilli (especially L. plantarum) predominated over enterococci and pediococci in Feta cheese during ripening.

The effects of starter culture addition on Turkish Beyaz brined cheese were investigated in several studies (Karakus and Alperden, 1995; Dağdemir et al., 2003; Hayaloğlu et al., 2004, 2005; Goncu and Alpkent, 2005; Kesenkas and Akbulut, 2006). In these studies, mixed mesophilic or thermophilic starter cultures (i.e., in different ratios Lactococcus plus Lactococcus or Lactococcus plus Lactobacillus) from several culture collections and even yeasts or lyophilized commercial cultures such as direct vat set were used for Beyaz cheesemaking. In another study on Beyaz cheese, the use of single strains of Lactococcus as a starter in cheese manufacture was investigated. The performance and relative contribution of 4 different single strains of lactococci on ripening characteristics and grading of Beyaz cheese during ripening were compared by Hayaloğlu et al. (2007). Although some efforts have been made in the determination of the natural flora, only a limited number of investigations have been conducted regarding the development of starter cultures from this flora for the manufacture of Beyaz cheese (Kayagil, 2006).
In this study, 8 lactic acid bacteria strains isolated from traditional cheeses were identified genotypically by $16 \mathrm{~S}$ rRNA gene sequence analysis and combined to form 2 different starter cultures. The effects of these starter culture combinations on the properties of Turkish Beyaz cheese were then evaluated from manufacture to the end of the ripening period.

\section{MATERIALS AND METHODS}

\section{Source of Lactic Acid Bacteria}

A total of 8 lactic acid bacteria were used in this study. These strains were previously isolated from different cheese samples and chosen from 135 lactobacilli, lactococci, and enterococci isolates (Öner et al., 2006b) based on the following criteria. Identification was carried out by biochemical tests (Kandler and Weiss, 1986). Lactic acid production ability of single-strain cultures during growth in skim milk for 6 and $24 \mathrm{~h}$, antimicrobial activity against Micrococcus luteus, proteolytic activity in skim milk for $24 \mathrm{~h}$, biogenic amine, and production of flavor compounds were determined. The best 8 strains were chosen according to acid production, hydrolysis of milk proteins in sterile skim milk, production of low contents of biogenic amine, and best flavor compounds for Beyaz cheese production.

\section{Identification of Starter Cultures}

Molecular characterization of 8 bacterial strains was further performed by amplified fragment length polymorphism analysis (AFLP) at Ghent University (Belgium). The cultures were cultivated and checked for purity after incubation at $28^{\circ} \mathrm{C}$ for $24 \mathrm{~h}$ under anaerobic conditions on M17 agar base (Oxoid CM785, Cambridge, UK) supplemented with $0.5 \%$ (wt/vol) lactose for lactococci or de Man, Rogosa, and Sharpe agar (MRS; Oxoid CM361) for lactobacilli. All cultures showed homogeneous growth. A well-isolated single colony was used as starting material for analysis. Genomic DNA was isolated by the method of Gevers et al. (2001) and digested simultaneously by 4 -base cutter and 6-base cutter restriction enzymes. Using this method, only a limited number of fragments of suitable size with 2 different cohesive ends were obtained. Small double-stranded DNA molecules (15-20 bp) containing 1 compatible end were ligated to the appropriate sticky end of the restriction fragments. Both adaptors were restriction half site-specific. These adaptors serve as binding sites for PCR primers. In the analysis, EcoR I (hexacutter) and TaqI (tetracutter) were used as restriction enzymes and the adaptors 5'-CTCGTA- 
GACTGCGTACC-3'; 3'-CTGACGCATGGTTAA5'and 5'-GACGATGAGTCCTGAC-3'; 3'-TACTCAGGACTGGC-5' were used for EcoR I- and TaqI-digested ends of fragments, respectively.

The PCR primers were designed according to adaptor sequences and selective amplification of restriction fragments was accomplished with the use of single selective nucleotides. The PCR primers were hybridized to the adaptors and the selective base, extending beyond the restriction site into the fragment on the $3^{\prime}$ end, led to the amplification of restriction fragments that had the appropriate complementary base adjacent to the restriction site. The primer combinations E01: 5'-GACTGCGTACCAATTCA-3' and T01: 5'-CGATGAGTCCTGACCGAA-3' were used for the hybridization of EcoR I- and TaqI-specific adaptors, respectively.

The PCR products were separated on a high-resolution polyacrylamide gel using a DNA sequencer (ABI 377, GMI, Dusseldorf, Germany). Fragments that contained an adaptor specific to the restriction half site created by the 6-bp cutter were visualized because of the 5 '-end labeling of the corresponding primer with the fluorescent dye FAM. The resulting electrophoretic patterns were tracked and normalized using GeneScan 3.1 software (Applera Corporation, Norwalk, CT). Normalized tables of peaks, containing fragments of 50 to $536 \mathrm{bp}$, were entered into BioNumerics 4.5 software (Applied Maths, Sint-Martens-Latem, Belgium). For numerical analysis, a data interval was delineated between the 75- and 500-bp bands of the internal size standard. Phylogenetic data analysis was based on band matching using the Dice coefficient and the UPGMA (unweighted pair group method with arithmetic mean) algorithm. The profiles were compared with the reference profiles of the lactic acid bacteria taxa (including bifidobacteria) that were currently available in the database (Ghent, Belgium).

\section{Starter Culture Composition}

To enable culture rotation during industrial-scale cheesemaking, 2 different starter culture combinations were prepared by using 8 strains of lactic acid bacteria. Combination 1 consisted of 3 strains of L. plantarum (16H, 23, and 87A) and Lc. lactis ssp. lactis YML62; combination 2 consisted of 2 strains of $L$. plantarum (1A and AK57B), L. paraplantarum 58A, and Lc. lactis A11i. A commercial starter culture (Wiesby Starter Cultures and Media, Niebüll, Germany) was used for the manufacture of the control cheeses. Before use, each lactococci strain was cultivated in M17 broth (Merck, Darmstadt, Germany) at $30^{\circ} \mathrm{C}$ for $24 \mathrm{~h}$ with 2 consecutive transfers $[1 \%$, (vol/vol), inoculum]; each lactobacilli strain was grown in MRS broth at the same conditions. For starter propagation, the cultures were transferred to $10 \%$ reconstituted skim milk that had been sterilized at $110^{\circ} \mathrm{C}$ for $15 \mathrm{~min}$. After incubation, an equal volume from each strain was taken and mixed to obtain the combinations under aseptic conditions.

\section{Cheesemaking and Sampling}

Raw cow's milk was clarified and pasteurized at $68^{\circ} \mathrm{C}$ for $15 \mathrm{~min}$ and cooled to $35^{\circ} \mathrm{C}$. It was then divided into 2 equal parts and inoculated with starter culture combination 1 and commercial starter culture separately at $1 \%$ level (experiment 1). The same procedure was repeated for the production of combination 2 cheeses (experiment 2). Calcium chloride was added to the milk at a level of $0.2 \mathrm{~g} / \mathrm{L}$. During all stages of cheesemaking, precautions were taken to avoid cross-contamination. The inoculated milk $\left(32^{\circ} \mathrm{C}\right)$ was held for approximately 30 min (until pH 6.3). The milk was coagulated by adding calf rennet (Mayasan, Istanbul, Turkey) for $90 \mathrm{~min}$. The coagulum was cut into cubes $\left(2 \mathrm{~cm}^{3}\right)$ and the curds were allowed to rest in the whey for 5 to $10 \mathrm{~min}$. The curds were pressed until whey drainage stopped. The pressure was provided by $20-\mathrm{kg}$ weights for each $100 \mathrm{~kg}$ of cheese milk (Yetişmeyen, 1995). The weights were then removed and the cheese was cut into $7-\mathrm{cm}^{3}$ blocks. The blocks were placed in brine $(14 \mathrm{~g} / 100 \mathrm{~mL}$ of $\mathrm{NaCl})$ for $2 \mathrm{~h}$. Tin cans were filled with cheese $(2 \times 500 \mathrm{~g})$ and brine and then closed. The cheese was ripened in the cans at $4^{\circ} \mathrm{C}$ for $90 \mathrm{~d}$. Cheese manufacture was performed in duplicate. Cheese samples were taken after 7 , 30, 60, and $90 \mathrm{~d}$ of ripening (Öner et al., 2006a).

\section{Chemical and Microbiological Analysis}

The percentages of DM, fat, fat in DM, salt, and salt in DM were determined according to the Turkish Standards (TS, 1978, 1986, 1995). Total N and water-soluble N (WSN) contents were determined by the Kjeldahl method (Bayrakli, 1987). The ripening index (RI) was calculated from the ratio of soluble $\mathrm{N}$ to total $\mathrm{N}$ (Alais, 1984). The $\mathrm{pH}$ values of the cheeses were measured with a $\mathrm{pH}$ meter (Hanna Instruments, Woonsocket, RI). All physicochemical analyses were performed in duplicate. Microbial analysis was performed according to Gobbetti et al. (1999) and Karahan et al. (2002). Polyacrylamide gel electrophoresis was performed using the method of Laemmli (1970). Sample preparations were made as described by Ong et al. (2006).

\section{Sensory Analysis}

The cheeses were graded at 7, 30,60, and $90 \mathrm{~d}$ of ripening by 6 graders (from the permanent staff at the 
Table 1. Identification results of lactic acid bacteria by classical and amplified fragment length polymorphism analysis (AFLP) methods

\begin{tabular}{lll}
\hline Strain & Name after classical phenotypic analysis & Name after AFLP analysis \\
\hline $16 \mathrm{H}$ & Lactobacillus sp. & L. plantarum \\
$87 \mathrm{~A}$ & Lactobacillus casei & L. plantarum \\
23 & Lactobacillus plantarum & L. plantarum \\
$58 \mathrm{~A}$ & Lactobacillus sp. & L. paraplantarum \\
$\mathrm{AK57B}$ & Lactobacillus sp. & L. plantarum \\
$1 \mathrm{~A}$ & Lactobacillus casei & L. plantarum \\
$\mathrm{A} 11 \mathrm{i}$ & Lactococcus lactis ssp. lactis & Lc. lactis ssp. lactis \\
YML62 & Lc. lactis ssp. lactis & Lc. lactis ssp. lactis \\
\hline
\end{tabular}

Food Engineering Department, SDU, Isparta, Turkey) familiar with Beyaz cheese. They graded the cheeses for appearance (0-20 scale), body and texture (0-35 scale), odor (0-10 scale), and flavor (0-35 scale) according to the Turkish Standards for Beyaz cheese as described in TS (TS, 1995).

\section{Statistical Analysis}

Multifactor ANOVA was used to compare the values of each microbiological and physicochemical change of cheese samples made using 2 types of cultures (combination 1 and combination 2) for 2 separate experiments at each sampling day. Multivariate test was used for comparing the data from the different ages of the cheese samples made with 2 types of culture. The least significant differences were obtained using Duncan's multiple-comparison test $(P<0.05)$. Statistical analysis was performed using SPSS (version 10.0, SPSS Inc., Chicago, IL).

\section{RESULTS AND DISCUSSION}

\section{Identification Results of Lactic Acid Bacteria}

Lactic acid bacteria that were used in starter culture combinations were phenotypically identified according to the reported scientific studies for Lactobacillus (Kandler and Weiss, 1986) and for Lactococcus (Bottazzi, 1993) species, and their technologically important properties were determined as shown in a previous study (Öner et al., 2006b). All lactobacilli were found to be facultative heterofermentative. Three of them were characterized up to the species level and the rest were identified only at the genus level. Cluster analysis with all available profiles of reference strains in the present lactic acid bacteria (LAB) database enabled $16 \mathrm{H}, 87 \mathrm{~A}, 23, \mathrm{AK} 57 \mathrm{~A}$, and $1 \mathrm{~A}$ to be identified as $L$. plantarum. The results also suggested that $58 \mathrm{~A}$ probably belonged to L. paraplantarum. Lactobacillus casei and L. plantarum show highly similar phenotypes except for some carbohydrate fermentation properties like mellibiose and raffinose (Kandler and Weiss, 1984). It is well known that biochemical identification results for LAB are often ubiquitous and unreliable, especially for strains that show atypical reactions; nevertheless, it is still an easy-to-use approach for identification of most common LAB species. One major reason for this mismatch might be ascribed to the loss or gain of plasmids because some carbohydrate fermentation capabilities are plasmid-encoded (Ahrné et al., 1989; Aquilanti et al., 2007). The lactococci strains used in the study were all identified as Lc. lactis ssp. lactis by traditional phenotypic tests.

Currently, species identification of lactic acid bacteria often relies on determination of the phylogenetic position using $16 \mathrm{~S}$ rRNA gene sequence analysis and further genotypic or phenotypic comparison with nearest neighbors. With regard to molecular characterization, AFLP was found to be effective in both differentiation and characterization of isolates. Given the high economic importance of lactic acid bacteria, the availability of methodologies able to characterize univocally the single species to the strain level is important. The strains within different subspecies are well distributed to different clusters in dendrogram analysis (Busconi et al., 2008). Lactobacillus plantarum isolates were clearly differentiated at the strain level, with a minimum similarity level of $65 \%$ and a maximum of $85 \%$. The isolate $58 \mathrm{~A}$ was clustered in L. paraplantarum reference strains and found to be distantly related to other $L$. plantarum isolates at a level of $55 \%$. Lactococcus lactis ssp. lactis isolates were also well separated, with a similarity level of $65 \%$. Summaries of both methods are given in Table 1 and the dendrograms of the AFLP patterns are shown in Figures 1 and 2.

Similar studies were performed for the identification and classification of lactic acid bacteria isolated from fermented foods as well as from the human gastrointestinal tract (Gancheva et al., 1999; Kunene et al., 2000; Ventura and Zink, 2002; Busconi et al., 2008). In these studies, AFLP technique was also applied to evaluate the biodiversity and origin of lactic acid bacteria populations. 


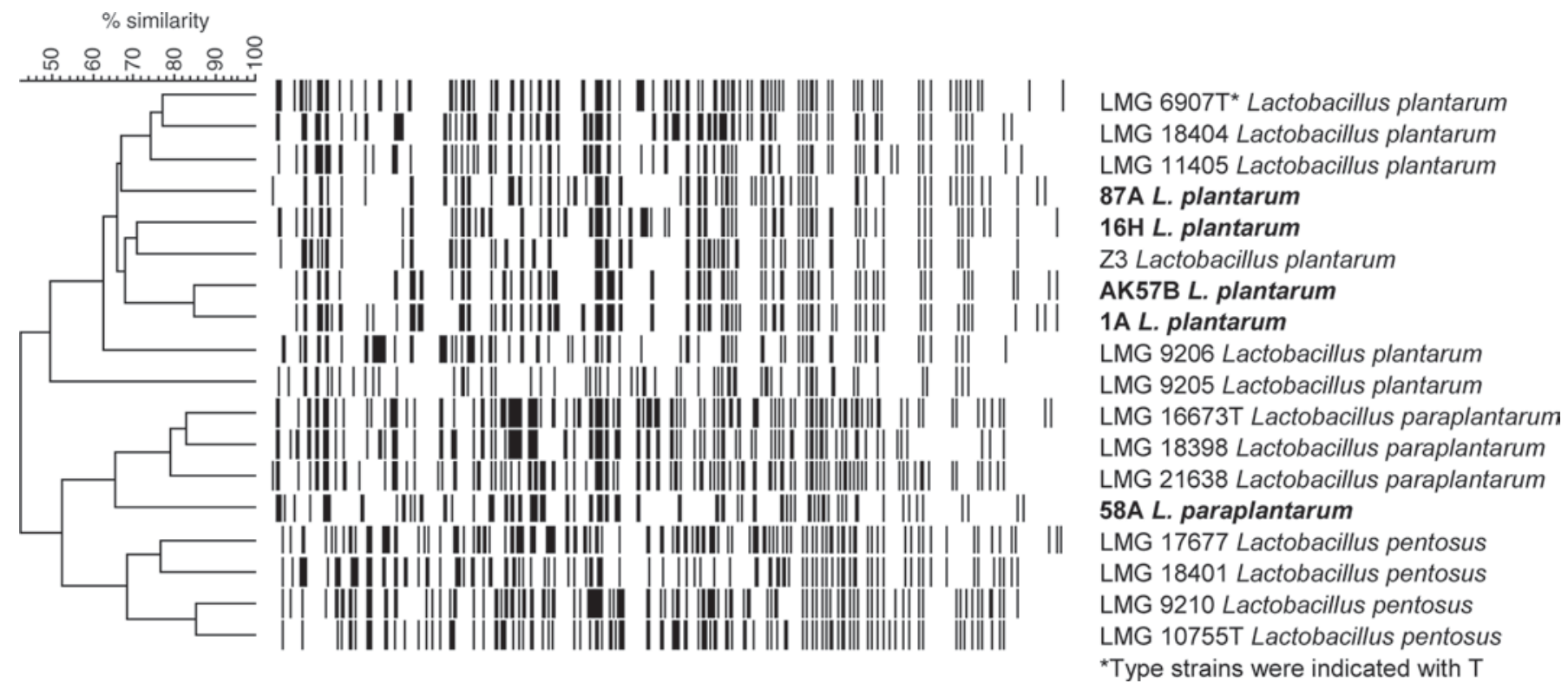

Figure 1. Unweighted pair group method with arithmetic mean (UPGMA) cluster analysis of amplified fragment length polymorphism analysis fingerprint profiles from reference strains of Lactobacillus plantarum, phylogenetically related species, and lactobacilli isolates.

Identification of lactic acid bacteria by phenotypic and especially genotypic methods and determination of their technologic properties were important for selection of starter cultures to produce Beyaz cheese as well as other fermented food products. Therefore, the studies on lactic acid bacteria concentrated on this subject. A similar study performed by Durlu-Özkaya et al. (2001) characterized isolates of lactic acid bacteria from Beyaz cheese made from raw ewes' milk without any starter cultures and determined some of their technologically important properties. Lactic acid bacteria from Beyaz cheese consisted of lactococci, enterococci, and lactobacilli. Seventy-seven isolated lactic acid bacteria were classified with phenotypic criteria and SDS-PAGE of whole-cell proteins. It was also suggested that the technological properties of lactococci and lactobacilli that

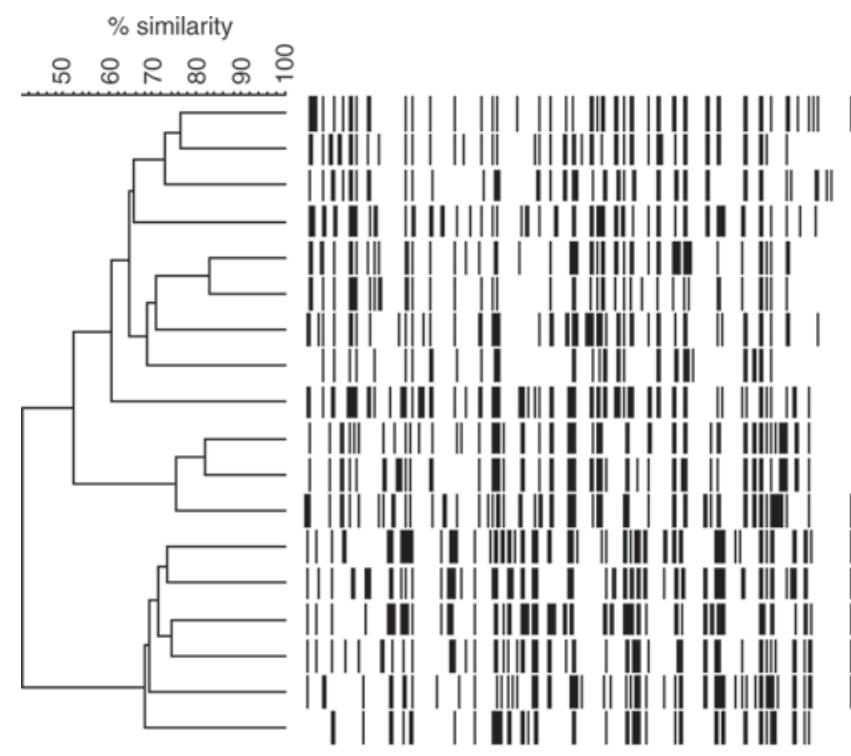

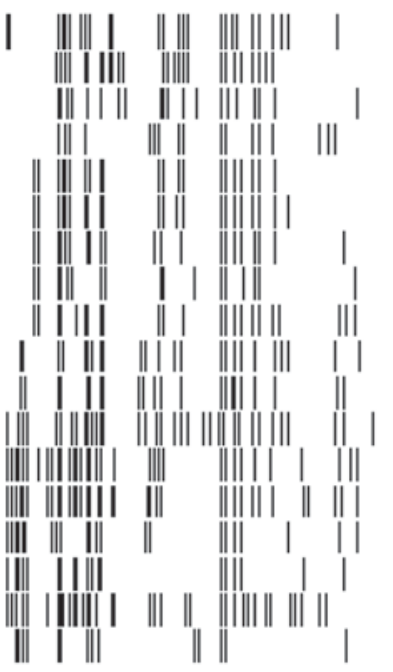

LMG 14418 Lactococcus lactis lactis LMG 6890T* Lactococcus lactis lactis YML 62 Lactococcus lactic lactis LMG 12162 Lactococcus lactis lactis LMG 8516 Lactococcus lactis lactis LMG 9451 Lactococcus lactis lactis LMG 9470 Lactococcus lactis lactis A11i Lactococcus lactis lactis LMG 9444 Lactococcus lactis lactis LMG 8520T Lactococcus lactis hordniae LMG 9462 Lactococcus lactis hordniae LMG 9461 Lactococcus lactis hordniae LMG 9428 Lactococcus lactis cremoris LMG 9459 Lactococcus lactis cremoris LMG 7951 Lactococcus lactis cremoris LMG 8505 Lactococcus lactis cremoris LMG 6897T Lactococcus lactis cremoris LMG 851512 Lactococcus lactis cremoris ${ }^{*}$ Type strains were indicated with $T$

Figure 2. Unweighted pair group method with arithmetic mean (UPGMA) cluster analysis of amplified fragment length polymorphism analysis fingerprint profiles from reference strains of Lactococcus lactis ssp. lactis and lactococci isolates. 
may contribute to ripening characteristics of the cheese were important as well as identification results.

\section{Chemical and Microbiological Properties of Cheeses}

To obtain 2 different starter cultures and to evaluate their effects on the properties of Beyaz cheese, data from chemical and microbial analysis are presented separately for each combination in Tables 2 and 3. During ripening, the DM, fat, and fat in DM levels remained almost stable $(P>0.05)$ for all experimental cheeses; however, salt, salt in DM, total N, and WSN levels and RI changed significantly $(P<0.05)$. These results are in agreement with many studies (Karakus and Alperden, 1995; Tzanetakis et al., 1995; Shakeel-Ur-Rehman et al., 1999; Hayaloğlu et al., 2004). Combination 1 had an important effect $(P<0.05)$ on the development of acidity in comparison with the commercial starter culture, whereas combination 2 showed the same effect at the end of the ripening period. Acid development is a very important criterion in the manufacture of cheeses ripened in brine because of the inhibitory effect of lactic acid on undesirable microorganisms and curd stability during brining (Abd El-Salam et al., 1993; Hayaloğlu et al., 2005). Both combinations developed acidity faster than the commercial starter culture. According to TS 591 (TS, 1995), $\mathrm{pH}$ is required to be higher than 4.5. All samples were in accordance with Turkish Standards for Beyaz cheese.

As a result of salt diffusion into the cheese, salt contents of all cheese groups increased significantly with ripening time $(P<0.05)$. However, the salt contents of samples were higher than given in TS 591 (TS, 1995) after $30 \mathrm{~d}$ because cheese samples began to melt.

The level of WSN compounds and total N gives information on cheese maturity or quality (Hayaloğlu, 2007). For the 7-d-old cheeses, the WSN contents were 0.18 to 0.19 in experiment 1 and 0.13 to 0.19 in experiment 2. However, in experiments 1 and 2, these quantities reached 0.37 to 0.40 and 0.89 to 0.46 in $90-d-$ old samples. As ripening proceeded, a rapid increase in WSN was observed in the 90-d-old control sample of experiment 1. Depending on ripening throughout storage, WSN also increased $(P<0.05)$. At the end of ripening, WSN levels and RI were the highest in the control cheeses of experiment 2 . These cheeses began to melt after $30 \mathrm{~d}$ and turned rancid at the end of storage period. Although the same commercial starter culture was used for both experiments, these differences could be because of milk quality. In experiment 2 , combination 2 cheeses also melted slightly; however, they did not turn rancid and were consumable. The different starter culture combinations had no significant effect on the level of WSN in the cheeses at any stages of ripening $(P<0.05)$. This indicates that the starter organisms in combinations do not make a direct contribution to the WSN content in cheese, as reported by Hayaloğlu et al. (2005).

The dynamics of the microbial groups were examined throughout ripening. As shown in Tables 2 and 3 , lactobacilli, lactococci, and total mesophilic aerobic bacteria $(\log \mathrm{cfu} / \mathrm{g})$ continued their presence in cheese. Lactobacilli levels displayed significant differences $(P<$ $0.05)$ from control cheeses over the course of ripening. On d 7, Lactobacillus counts were highest in the cheeses to which the culture combinations had been added. Lactobacillus counts decreased 1 log unit in combination 1 cheeses during the first $30 \mathrm{~d}$ of ripening and then remained constant at around $10^{7} \mathrm{cfu} / \mathrm{g}$. Levels of lactobacilli in experiment 2 cheeses also remained unchanged during the ripening period (Table 3 ). As shown by other authors (Peterson and Marshall, 1990; McSweeney et al., 1994), in conventional cheesemaking, starter lactic acid bacteria grow rapidly in cheese milk and curd during manufacture, reaching 8.0 to $9.0 \mathrm{log} \mathrm{cfu} g / \mathrm{L}$, but subsequently decline at a rate dependent on the strain to approximately $1 \%$ of the maximum number within 1 mo of ripening. The decrease in starter cell numbers during cheese ripening is caused by the low adaptability to the hostile environment in the interior of the cheese, which has low $\mathrm{pH}$ and a high salt content, lacks a fermentable carbohydrate, and may contain bacteriocins (Fox et al., 1996; Cagno et al., 2006).

There were no significant differences in lactococcal levels among the batches on $\mathrm{d} 7$ in experiment 1 (Table $2)$. Significant differences $(P<0.05)$ were apparent from $\mathrm{d}$ 30. Counts of lactococci in control cheeses decreased slightly over the ripening period; however, in combination 1, cheeses remained almost stable. In experiment 2, there were significant differences between control and combination 2 cheeses $(P<0.05)$; however, the cell counts of each batch did not vary throughout ripening. This finding indicates that the lactobacilli and lactococci selected for use in the culture combinations added in these experiments survived and adopted well in the cheeses.

Coliforms, yeasts, and molds were not detected in any of the cheeses throughout the ripening period. The initial contamination by Enterobacteriaceae and coliforms could be lower because of the winter season when the contamination count is thought to be lower than in summer. On the other hand, as expected, pasteurization reduced coliforms levels and contaminations were prevented by taking sanitary precautions. The microflora present in the environment in cheesemaking plants is an important factor, particularly in the case of cheeses made from pasteurized milks (Casalta and Corté, 1997). 
Table 2. Chemical and microbiological characteristics of experiment 1 cheeses during storage period

\begin{tabular}{|c|c|c|c|c|c|c|c|c|}
\hline \multirow[b]{2}{*}{ Item $^{1}$} & \multicolumn{2}{|c|}{ Day 7} & \multicolumn{2}{|c|}{ Day 30} & \multicolumn{2}{|c|}{ Day 60} & \multicolumn{2}{|c|}{ Day 90} \\
\hline & Control & Combination 1 & Control & Combination 1 & Control & Combination 1 & Control & Combination 1 \\
\hline $\mathrm{pH}$ & $4.66 \pm 0.09^{\mathrm{c}}$ & $4.36 \pm 0.08^{\mathrm{d}}$ & $5.12 \pm 0.03^{\mathrm{a}}$ & $4.89 \pm 0.13^{\mathrm{b}}$ & $4.96 \pm 0.01^{\mathrm{ab}}$ & $4.63 \pm 0.16^{\mathrm{c}}$ & $4.88 \pm 0.04^{\mathrm{b}}$ & $4.65 \pm 0.19^{\mathrm{c}}$ \\
\hline $\mathrm{DM}(\%)$ & $35.98 \pm 1.96^{\mathrm{a}}$ & $35.61 \pm 2.15^{\mathrm{a}}$ & $35.89 \pm 3.59^{\mathrm{a}}$ & $36.35 \pm 3.12^{\mathrm{a}}$ & $35.70 \pm 2.86^{\mathrm{a}}$ & $37.26 \pm 2.80^{\mathrm{a}}$ & $34.93 \pm 2.38^{\mathrm{a}}$ & $35.46 \pm 2.22^{\mathrm{a}}$ \\
\hline Fat $(\%)$ & $18.50 \pm 2.82^{\mathrm{a}}$ & $18.50 \pm 2.82^{\mathrm{a}}$ & $18.50 \pm 2.82^{\mathrm{a}}$ & $18.50 \pm 2.82^{\mathrm{a}}$ & $18.00 \pm 2.82^{\mathrm{a}}$ & $19.25 \pm 3.88^{\mathrm{a}}$ & $19.25 \pm 3.18^{\mathrm{a}}$ & $19.00 \pm 3.53^{\mathrm{a}}$ \\
\hline FDM $(\%)$ & $51.26 \pm 5.06^{\mathrm{a}}$ & $51.79 \pm 4.80^{\mathrm{a}}$ & $51.40 \pm 2.73^{\mathrm{a}}$ & $50.74 \pm 3.41^{\mathrm{a}}$ & $50.25 \pm 3.88^{\mathrm{a}}$ & $51.41 \pm 6.57^{\mathrm{a}}$ & $54.91 \pm 5.36^{\mathrm{a}}$ & $53.37 \pm 6.63^{\mathrm{a}}$ \\
\hline Salt (\%) & $2.05 \pm 0.04^{\mathrm{d}}$ & $2.07 \pm 0.05^{\mathrm{cd}}$ & $2.18 \pm 0.18^{\mathrm{cd}}$ & $2.34 \pm 0.03^{\mathrm{cd}}$ & $2.45 \pm 0.16^{\mathrm{cd}}$ & $3.04 \pm 0.33^{\mathrm{b}}$ & $2.50 \pm 0.41^{\mathrm{c}}$ & $3.74 \pm 0.33^{\mathrm{a}}$ \\
\hline SDM (\%) & $5.69 \pm 1.10^{\mathrm{d}}$ & $5.81 \pm 1.06^{\mathrm{d}}$ & $6.07 \pm 5.61^{\mathrm{cd}}$ & $6.43 \pm 2.31^{\mathrm{cd}}$ & $6.86 \pm 0.00^{\text {bcd }}$ & $8.15 \pm 0.39^{\mathrm{b}}$ & $10.02 \pm 2.17^{\mathrm{bc}}$ & $10.54 \pm 0.13^{\mathrm{a}}$ \\
\hline Total N (\%) & $1.95 \pm 0.03^{\mathrm{ab}}$ & $1.96 \pm 0.10^{\mathrm{ab}}$ & $2.00 \pm 0.26^{\mathrm{ab}}$ & $2.08 \pm 0.02^{\mathrm{a}}$ & $1.72 \pm 0.06^{\mathrm{cd}}$ & $1.93 \pm 0.03^{\mathrm{ab}}$ & $1.58 \pm 0.04^{\mathrm{d}}$ & $1.80 \pm 0.07^{\mathrm{bc}}$ \\
\hline WSN $(\%)$ & $0.18 \pm 0.02^{\mathrm{e}}$ & $0.19 \pm 0.01^{\mathrm{de}}$ & $0.21 \pm 0.09^{\mathrm{d}}$ & $0.27 \pm 0.01^{\mathrm{c}}$ & $0.27 \pm 0.16^{\mathrm{c}}$ & $0.35 \pm 0.14^{\mathrm{b}}$ & $0.37 \pm 0.14^{\mathrm{b}}$ & $0.40 \pm 0.16^{\mathrm{a}}$ \\
\hline RI & $8.95 \pm 0.02^{\mathrm{e}}$ & $9.41 \pm 0.05^{\mathrm{e}}$ & $10.47 \pm 0.18^{\mathrm{de}}$ & $12.98 \pm 0.02^{\mathrm{d}}$ & $15.65 \pm 0.11^{\mathrm{c}}$ & $18.08 \pm 0.08^{\mathrm{b}}$ & $23.41 \pm 0.09^{\mathrm{a}}$ & $22.16 \pm 0.12^{\mathrm{a}}$ \\
\hline Lactobacilli (log cfu/g) & $5.90 \pm 0.25^{\mathrm{c}}$ & $8.93 \pm 0.55^{\mathrm{a}}$ & $5.71 \pm 0.07^{\mathrm{c}}$ & $7.23 \pm 0.65^{\mathrm{b}}$ & $5.85 \pm 0.84^{\mathrm{c}}$ & $7.40 \pm 0.78^{\mathrm{b}}$ & $6.65 \pm 0.49^{\mathrm{bc}}$ & $7.53 \pm 0.59^{\mathrm{b}}$ \\
\hline Lactococci (log cfu/g) & $8.70 \pm 0.48^{\mathrm{ba}}$ & $9.65 \pm 0.13^{\mathrm{a}}$ & $7.62 \pm 1.01^{\mathrm{cd}}$ & $9.16 \pm 0.27^{\mathrm{ba}}$ & $8.51 \pm 0.05^{\mathrm{bc}}$ & & $8.35 \pm 0.08^{\text {bcd }}$ & $9.06 \pm 0.02^{\text {ba }}$ \\
\hline TMAB $(\log \mathrm{cfu} / \mathrm{g})$ & $9.00 \pm 0.00^{\mathrm{a}}$ & $8.51 \pm 0.21^{\mathrm{a}}$ & $6.85 \pm 0.74^{\mathrm{b}}$ & $7.63 \pm 0.68^{\mathrm{ab}}$ & $7.83 \pm 0.12^{\mathrm{ab}}$ & $7.59 \pm 0.63^{\mathrm{ab}}$ & $8.20 \pm 1.18^{\mathrm{a}}$ & $7.56 \pm 0.47^{\mathrm{ab}}$ \\
\hline
\end{tabular}

${ }^{\mathrm{a} e} \mathrm{e}$ Means in the same row with different superscript letters are significantly different $(P<0.05)$.

${ }^{1} \mathrm{FDM}=$ fat in dry matter; $\mathrm{SDM}=$ salt in dry matter; WSN $=$ water-soluble N; RI = ripening index; TMAB = total mesophilic aerobic bacteria.

Table 3. Chemical and microbiological characteristics of experiment 2 cheeses during storage period

\begin{tabular}{|c|c|c|c|c|c|c|c|c|}
\hline \multirow[b]{2}{*}{ Item $^{1}$} & \multicolumn{2}{|c|}{ Day 7} & \multicolumn{2}{|c|}{ Day 30} & \multicolumn{2}{|c|}{ Day 60} & \multicolumn{2}{|c|}{ Day 90} \\
\hline & Control & Combination 2 & Control & Combination 2 & Control & Combination 2 & Control & Combination 2 \\
\hline $\mathrm{pH}$ & $5.26 \pm 0.08^{\mathrm{a}}$ & $5.25 \pm 0.06^{\mathrm{a}}$ & $4.66 \pm 0.09^{b}$ & $4.65 \pm 0.00^{\mathrm{b}}$ & $4.73 \pm 0.08^{\mathrm{b}}$ & $4.67 \pm 0.02^{\mathrm{b}}$ & $4.62 \pm 0.00^{\mathrm{b}}$ & $4.50 \pm 0.09^{\mathrm{c}}$ \\
\hline $\mathrm{DM}(\%)$ & $36.62 \pm 1.49^{\mathrm{b}}$ & $39.95 \pm 1.94^{\mathrm{a}}$ & $36.89 \pm 0^{\mathrm{b}}$ & $38.16 \pm 0.12^{\mathrm{ab}}$ & $37.74 \pm 1.16^{\mathrm{ab}}$ & $38.78 \pm 1.42^{\mathrm{ab}}$ & $38.00 \pm 0.75^{\mathrm{ab}}$ & $36.61 \pm 1.62^{\mathrm{b}}$ \\
\hline Fat $(\%)$ & $20.37 \pm 0.17^{\mathrm{a}}$ & $20.00 \pm 2.47^{\mathrm{ab}}$ & $319.50 \pm 0^{\mathrm{ab}}$ & $18.25 \pm 0.35^{\mathrm{b}}$ & $19.50 \pm 0^{\mathrm{ab}}$ & $18.75 \pm 1.06^{\mathrm{ab}}$ & $19.50 \pm 0^{\mathrm{ab}}$ & $18.75 \pm 1.06^{\mathrm{ab}}$ \\
\hline FDM $(\%)$ & $55.67 \pm 1.78^{\mathrm{a}}$ & $49.96 \pm 3.76^{\mathrm{bcd}}$ & $52.84 \pm 0.00^{\mathrm{ab}}$ & $47.82 \pm 0.77^{\mathrm{d}}$ & $51.68 \pm 1.58^{\mathrm{b}}$ & $48.32 \pm 0.96^{\mathrm{cd}}$ & $51.32 \pm 1.02^{\mathrm{bc}}$ & $51.18 \pm 0.62^{\mathrm{bc}}$ \\
\hline Salt $(\%)$ & $2.98 \pm 0.08^{\mathrm{e}}$ & $4.35 \pm 0.04^{\mathrm{abc}}$ & $3.68 \pm 0.41^{\mathrm{d}}$ & $4.14 \pm 0.16^{\mathrm{bc}}$ & $3.69 \pm 0.07^{\mathrm{d}}$ & $4.46 \pm 0.12^{\mathrm{ba}}$ & $4.03 \pm 0.24^{\mathrm{cd}}$ & $4.61 \pm 0.33^{\mathrm{a}}$ \\
\hline $\operatorname{SDM}(\%)$ & $8.14 \pm 0.78^{\mathrm{d}}$ & $10.88 \pm 0.99^{\mathrm{bc}}$ & $9.99 \pm 0.20^{\mathrm{c}}$ & $10.87 \pm 0.14^{\mathrm{bc}}$ & $9.78 \pm 0.61^{\mathrm{c}}$ & $11.52 \pm 0.77^{\mathrm{ab}}$ & $10.62 \pm 0.50^{\mathrm{bc}}$ & $12.60 \pm 0.97^{\mathrm{a}}$ \\
\hline Total N (\%) & $2.57 \pm 0.50^{\mathrm{a}}$ & $2.21 \pm 0.13^{\mathrm{ab}}$ & $2.51 \pm 0.52^{\mathrm{bc}}$ & $2.03 \pm 0.25^{\mathrm{bc}}$ & $2.24 \pm 0.50^{\mathrm{bc}}$ & $1.9 \pm 0.33^{\mathrm{bc}}$ & $2.38 \pm 0.01^{\mathrm{bc}}$ & $1.81 \pm 0.26^{\mathrm{bc}}$ \\
\hline WSN $(\%)$ & $0.16 \pm 0.002^{\mathrm{d}}$ & $0.13 \pm 0.04^{\mathrm{e}}$ & $0.18 \pm 0.02^{\mathrm{d}}$ & $0.14 \pm 0.001^{\mathrm{e}}$ & $0.44 \pm 0.02^{\mathrm{b}}$ & $0.24 \pm 0.01^{\mathrm{c}}$ & $0.67 \pm 0.02^{\mathrm{b}}$ & $0.46 \pm 0.02^{\mathrm{b}}$ \\
\hline RI & $6.59 \pm 0.25^{\mathrm{d}}$ & $5.73 \pm 0.06^{\mathrm{d}}$ & $8.55 \pm 0.05^{\mathrm{d}}$ & $6.69 \pm 0.12^{\mathrm{d}}$ & $25.36 \pm 0.045^{\mathrm{b}}$ & $12.63 \pm 0.17^{\mathrm{c}}$ & $28.24 \pm 0.01^{\mathrm{b}}$ & $25.69 \pm 0.14^{\mathrm{b}}$ \\
\hline Lactobacilli (log cfu/g) & $7.81 \pm 0.13^{\mathrm{b}}$ & $8.45 \pm 0.25^{\mathrm{a}}$ & $8.39 \pm 0.71^{\mathrm{a}}$ & $8.68 \pm 0.34^{\mathrm{a}}$ & $7.86 \pm 0.00^{\mathrm{b}}$ & $8.68 \pm 0.02^{\mathrm{a}}$ & $7.81 \pm 0.07^{\mathrm{b}}$ & $8.84 \pm 0.22^{\mathrm{a}}$ \\
\hline Lactococci (log cfu/g) & $7.85 \pm 0.20^{\mathrm{b}}$ & $8.85 \pm 0.10^{\mathrm{a}}$ & $7.89 \pm 0.01^{\mathrm{b}}$ & $8.91 \pm 0.06^{\mathrm{a}}$ & $7.91 \pm 0.11^{\mathrm{b}}$ & $8.90 \pm 0.12^{\mathrm{a}}$ & $8.02 \pm 0.25^{\mathrm{b}}$ & $8.91 \pm 0.11^{\mathrm{a}}$ \\
\hline TMAB $(\log \mathrm{cfu} / \mathrm{g})$ & $7.90 \pm 0.03^{\mathrm{b}}$ & $8.94 \pm 0.06^{\mathrm{a}}$ & $7.89 \pm 0.02^{\mathrm{b}}$ & $8.92 \pm 0.06^{\mathrm{a}}$ & $7.96 \pm 0.11^{\mathrm{b}}$ & $8.83 \pm 0.02^{\mathrm{a}}$ & $7.96 \pm 0.20^{\mathrm{b}}$ & $8.89 \pm 0.05^{\mathrm{a}}$ \\
\hline
\end{tabular}

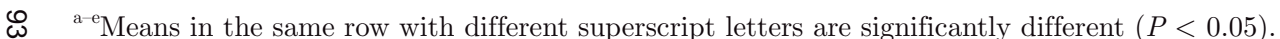

Z $\quad{ }^{1} \mathrm{FDM}=$ fat in dry matter; $\mathrm{SDM}=$ salt in dry matter; WSN $=$ water-soluble $\mathrm{N}$; RI = ripening index; TMAB = total mesophilic aerobic bacteria 


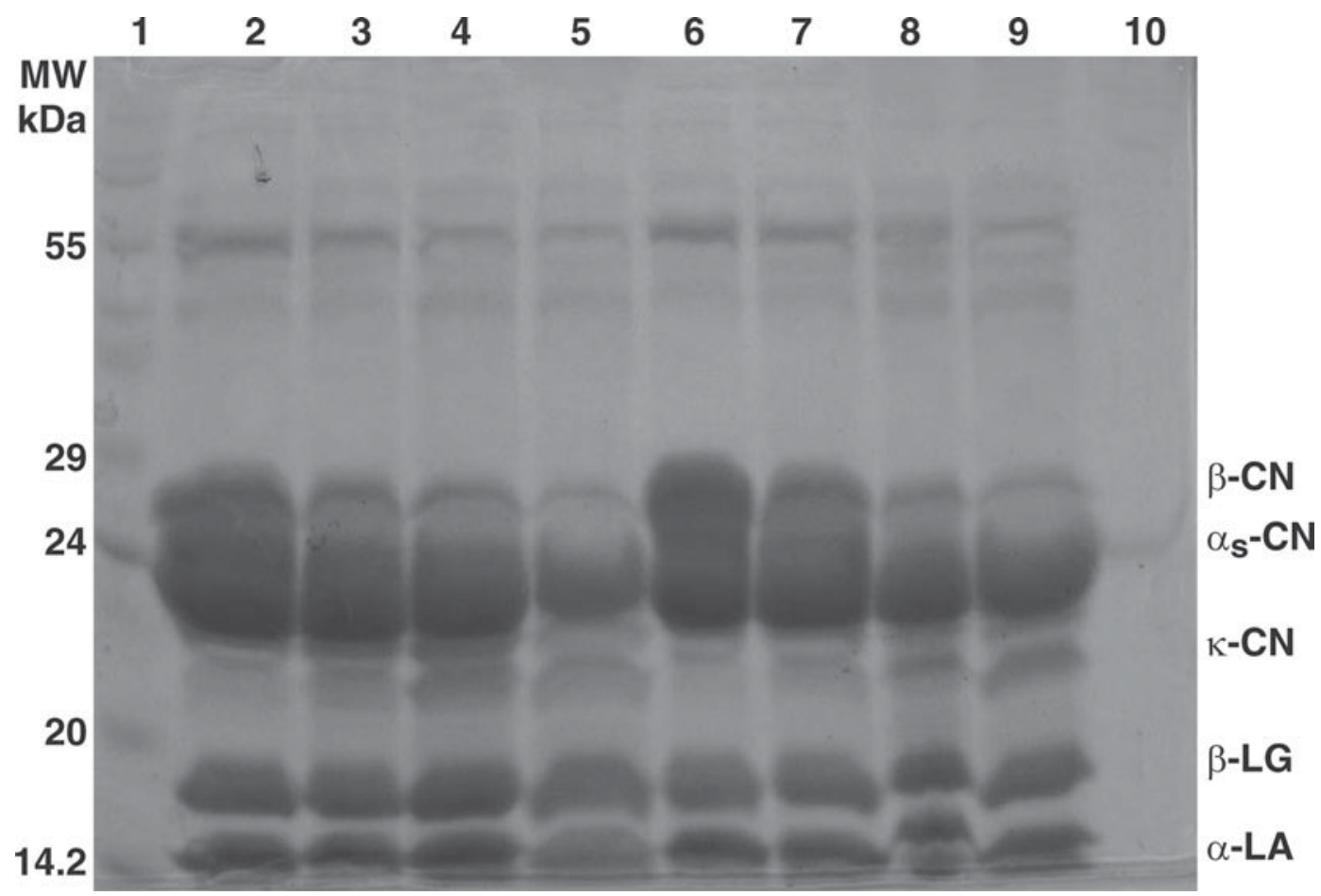

Figure 3. Degradation products during ripening in experiment 1. Lane 1: protein marker; lanes 2 to 5: control cheeses after 7, 30, 60, and 90 $\mathrm{d}$ of ripening, respectively; lanes 6 to 9: combination 1 cheeses after 7, 30, 60, and $90 \mathrm{~d}$ of ripening, respectively; lane 10 : $\alpha_{S^{-}} \mathrm{CN}$ marker. MW $=$ molecular weight.

\section{SDS-PAGE Patterns}

The SDS-PAGE electrophoretogram of the experiment 1 cheeses during ripening is shown in Figure 3. Casein hydrolysis was observed from 7 to $90 \mathrm{~d}$ for both $\beta$ - and $\alpha_{S}$-caseins in cheese samples. At the beginning of the ripening period, no differences were seen between intensities of casein fractions of cheeses. Hydrolysis of the caseins accelerated, and $\beta$ - and $\alpha_{\mathrm{S}}$-caseins especially began to degrade slightly after 30 d. $\alpha_{S^{-}}$Casein was observed with a high intensity at the beginning of ripening, and $\alpha_{S^{-}}$casein hydrolysis was observed as being lower in both cheese samples at the end of ripen- ing. These results do not seem to be in agreement with other findings (Katsiari et al., 2002; Poveda et al., 2003; Hayaloğlu et al., 2005; Tarakçı and Tuncturk, 2008). It has been established that $\beta$-casein is more resistant to proteolysis than $\alpha_{S^{-}}$casein, especially in the cheese matrix, either by calf rennet or starter enzymes, owing to its structure and particularly its tendency to associate (McSweeney et al., 1993). However, different findings regarding $\alpha_{S}$-casein degradation rate in the literature are present because of the differences in milk used, manufacturing procedure, and ripening conditions (Fox et al., 1993). Another possible reason for this pattern is the formation of hydrolysis products ( $\beta$-II peptides)

Table 4. Sensory analyses ${ }^{1}$ of experiment 1 cheeses $( \pm \mathrm{SD})$

\begin{tabular}{|c|c|c|c|c|c|c|}
\hline Item & Day & Appearance & Texture & Odor & Flavor & Total score \\
\hline \multirow[t]{4}{*}{ Combination 1} & 7 & $18.000 \pm 2.000^{\mathrm{a}}$ & $32.000 \pm 1.000^{\mathrm{a}}$ & $8.000 \pm 2.000^{\mathrm{a}}$ & $30.000 \pm 2.000^{\mathrm{ab}}$ & $88.000 \pm 7.000^{\mathrm{ab}}$ \\
\hline & 30 & $20.000 \pm 0.000^{\mathrm{a}}$ & $32.333 \pm 1.154^{\mathrm{a}}$ & $9.000 \pm 0.000^{\mathrm{a}}$ & $33.000 \pm 0.000^{\mathrm{a}}$ & $94.333 \pm 1.154^{\mathrm{a}}$ \\
\hline & 60 & $18.666 \pm 1.154^{\mathrm{a}}$ & $31.666 \pm 2.886^{\mathrm{a}}$ & $9.333 \pm 0.577^{\mathrm{a}}$ & $31.666 \pm 2.886^{\mathrm{a}}$ & $91.333 \pm 7.505^{\mathrm{a}}$ \\
\hline & 90 & $19.323 \pm 1.723^{\mathrm{a}}$ & $27.000 \pm 1.732^{\mathrm{ab}}$ & $9.333 \pm 1.154^{\mathrm{a}}$ & $27.000 \pm 5.196^{\mathrm{ab}}$ & $82.656 \pm 4.650^{\mathrm{abc}}$ \\
\hline \multirow[t]{4}{*}{ Control } & 7 & $17.000 \pm 1.000^{\mathrm{ab}}$ & $21.000 \pm 2.645^{\mathrm{bc}}$ & $8.000 \pm 0.000^{\mathrm{a}}$ & $23.000 \pm 0.000^{\mathrm{b}}$ & $69.000 \pm 2.000^{\mathrm{cd}}$ \\
\hline & 30 & $16.000 \pm 0.000^{\mathrm{ab}}$ & $19.333 \pm 4.041^{\mathrm{cd}}$ & $9.000 \pm 0.000^{\mathrm{a}}$ & $28.333 \pm 4.041^{\mathrm{ab}}$ & $72.666 \pm 7.637^{\mathrm{bcd}}$ \\
\hline & 60 & $11.000 \pm 2.645^{\mathrm{b}}$ & $12.000 \pm 3.464^{\mathrm{d}}$ & $9.000 \pm 0.000^{\mathrm{a}}$ & $26.333 \pm 2.309^{\mathrm{ab}}$ & $58.333 \pm 8.386^{\mathrm{de}}$ \\
\hline & 90 & $15.000 \pm 6.000^{\mathrm{ab}}$ & $12.666 \pm 4.618^{\mathrm{d}}$ & $8.666 \pm 0.577^{\mathrm{a}}$ & $16.000 \pm 0.000^{\mathrm{c}}$ & $52.333 \pm 9.712^{\mathrm{e}}$ \\
\hline
\end{tabular}

\footnotetext{
${ }^{\mathrm{a}-\mathrm{e}}$ Means in the same row with different superscript letters are significantly different $(P<0.05)$.

${ }^{1}$ Sensory analyses included analysis of appearance (0-20 scale), texture (0-35 scale), odor (0-10 scale), and flavor (0-35 scale).
} 
Table 5. Sensory analyses ${ }^{1}$ of experiment 2 cheeses $( \pm$ SD)

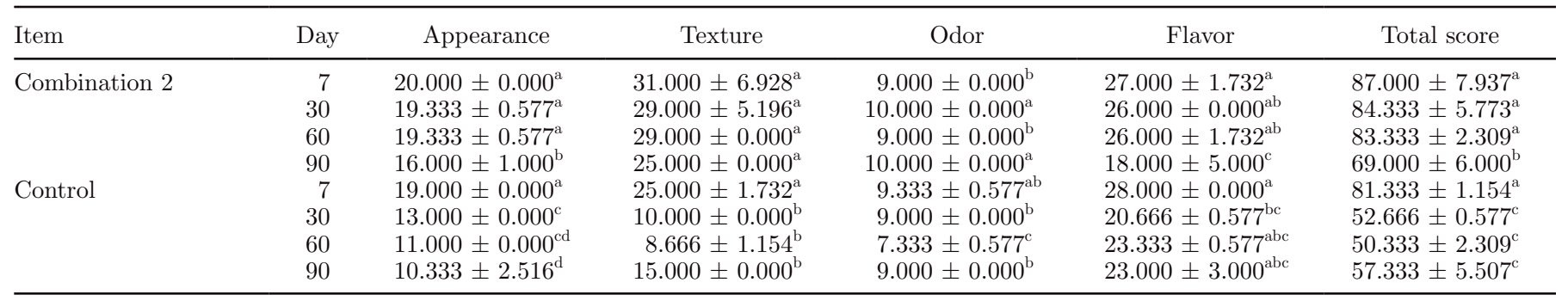

${ }^{\mathrm{a}-\mathrm{d}}$ Means in the same row with different superscript letters are significantly different $(P<0.05)$.

${ }^{1}$ Sensory analyses included analysis of appearance (0-20 scale), texture (0-35 scale), odor (0-10 scale), and flavor (0-35 scale).

from $\beta$-casein with very similar electrophoretic mobilities to those of the $\alpha_{S}$-casein bands and of densitometrical increase of the $\alpha_{S^{-}}$casein zone (Carretero et al., 1994; Trujillo et al., 2002). On the other hand, starter culture composition and salt content of Beyaz cheeses have an effect on $\beta$-casein degradation. In the white-brined cheeses, the principal proteolytic agents are the residual coagulant and enzymes from starters or the indigenous microflora. Tuncturk et al. (2008) found that breakdown of $\beta$-caseins in cheeses with different starter cultures (yogurt culture and helveticus culture) was higher than in the other experimental cheeses at the end of the ripening period. In another study, it was determined that accelerated salt concentration $(>5 \%)$ prevented hydrolysis of $\beta$-casein by chymosine (Topçu, 2004). In our study, salt concentration of cheeses was less than 5\%; therefore, degradation of casein fractions may change.

\section{Sensory Analysis}

The mean sensory scores of the experimental cheeses are shown in Tables 4 and 5. No significant differences were determined between our starter culture combinations ( 1 and 2 ) and control cheeses at the first week except for the texture of the control cheeses in experiment 1. However, the graders reported that combination 1 cheeses had more flavor or flavor intensity throughout ripening period. At the end of ripening, bitter flavor and deterioration of texture were detected in the control cheeses in experiment 2. Control cheeses in both experiments received considerably lower total scores than the other cheeses after $30 \mathrm{~d}$. A soft texture was determined in experiment 2 cheeses after $60 \mathrm{~d}$ of ripening; this may be linked to the degradation of $\alpha_{\mathrm{S} 1}$-casein (Fenelon et al., 1999). Therefore, combination 1 and 2 cheeses revealed similar sensory scores and were significantly different $(P<0.05)$ from control cheeses. Both starter culture combinations were found to be suitable for Beyaz cheese manufacture.

\section{CONCLUSIONS}

The results clearly showed that the starter cultures affected the chemical and microbiological properties of Beyaz cheese during ripening. Starter culture combinations supported some important Beyaz cheese properties such as ripening characteristics, $\mathrm{pH}$, and lactobacilli and lactoccocci counts. The RI of all groups was found to be similar at the end of the ripening period. $\beta$-Casein in experimental cheeses degraded and its amount decreased during ripening. All analyses showed that when their quality attributes were comparable to commercial starter culture, Beyaz cheeses with these combinations were satisfactory. Moreover, the sensory characteristics of these cheeses were rated higher than those of the control cheeses.

\section{ACKNOWLEDGMENTS}

This work was funded by TR Prime Ministry State Planning Organization, Turkey (project no. 2005K120570). We thank Ender Olcayto (Scotland) and Birol Kılıç (SDU, Isparta, Turkey) for editing the language of the manuscript.

\section{REFERENCES}

Abd El-Salam, M. H., E. Alichanidis, and G. K. Zerfiridis. 1993. Domiati and Feta type cheeses. Pages 301-335 in Cheese: Chemistry, Physics and Microbiology. Vol. 2. 2nd ed. P.F. Fox, ed. Chapman and Hall, London, UK.

Ahrné, S., G. Molin, and S. Stahl. 1989. Plasmids in Lactobacillus strains isolated from meat and meat products. Syst. Appl. Microbiol. 11:320-325.

Alais, C. 1984. Science Du Lait. 4th ed. Spaic, Paris, France.

Aquilanti, L., E. Zannini, A. Zocchetti, A. Osimani, and F. Clementi. 2007. Polyphasic characterization of indigenous lactobacilli and lactococci from PDO Canestrato Pugliese cheese. LWT-Food Sci. Technol. 40:1146-1155.

Bașyiğit Kılıç, G., H. Kuleașan, İ. Eralp, and A. G. Karahan. 2009 Manufacture of Turkish Beyaz cheese added with probiotic strains. LWT_Food Sci. Technol. 42:1003-1008.

Bayrakli, F. 1987. Toprak Bitki Analizleri. Ondokuz Mayıs Üniversitesi Ziraat Fakültesi, Samsun, Turkey.

Bintsis, T., and P. Papademas. 2002. Microbiological quality of whitebrined cheeses: A review. Int. J. Dairy Technol. 55:113-120. 
Bottazzi, V. 1993. Applicazioni biotecnologiche di microrganismi lattiero-caseari. Pages 223-306 in Microbiologia e Biotecnologia Lattiero-Casearia. Edagricole, Bologna, Italy.

Busconi, M., S. Reggi, and C. Fogher. 2008. Evaluation of biodiversity of lactic acid bacteria microbiota in the calf intestinal tracts. Antonie Van Leeuwenhoek Int. J. G 94:145-155.

Cagno, R. D., M. Quinto, A. Corsetti, F. Minervini, and M. Gobetti. 2006. Assessing the proteolytic and lipolytic activities of single strains of mesophilic lactobacilli as adjunct cultures using a Caciotta cheese model system. Int. Dairy J. 16:119-130.

Carretero, C., A. J. Trujillo, M. Mor-Mur, R. Pla, and B. Guamis. 1994. Electrophoretic study of casein break-down during ripening of goats' milk cheese. J. Agric. Food Chem. 42:1546-1550.

Casalta, E., and I. Corté. 1997. Interactions between starter lactic acid bacteria and milk indigenous microflora. Pages 139-145 in Proc. 4th Plenary Meeting Portugal.

Dağdemir, E., Ş. Çelik, and S. Özdemir. 2003. The effects of some starter cultures on the properties of Turkish White cheese. Int. J. Dairy Technol. 56:215-218.

Dağdemir, E., and S. Özdemir. 2008. Ksantin oksidaz enzimi ve sütteki önemi. Türkiye 10. Gida Kongresi, Erzurum, Turkey.

Durlu-Özkaya, F., V. Xanthopoulos, N. Tunail, and E. LitopoulouTzanetaki. 2001. Technologically important properties of lactic acid bacteria isolates from Beyaz cheese made from raw ewes' milk. J. Appl. Microbiol. 91:861-870.

Fenelon, M. A., T. P. Guinee, and W. J. Reville. 1999. Characteristics of reduced-fat Cheddar prepared from blending of full-fat and skim cheese curds at whey drainage. Milchwissenschaft 54:506-510.

Fox, P. F., J. Law, P. L. H. Mcsweeney, and J. Wallace. 1993. Biochemistry of cheese ripening. Pages 389-439 in Cheese: Chemistry, Physics and Microbiology. Vol. 1. P.F. Fox, ed. Chapman and Hall, London, U.K.

Fox, P. F., J. M. Wallace, S. Morgan, C. M. Lynch, E. J. Niland, and J. Tobin. 1996. Acceleration of cheese ripening. Antonie Van Leeuwenhoek Int. J. G 70:271-297.

Gancheva, A., B. Pot, K. Vanhonacker, B. Hoste, and K. A. Kersters. 1999. Polyphasic approach towards the identification of strains belonging to Lactobacillus acidophilus and related species. Syst. Appl. Microbiol. 22:573-585.

Gevers, D., G. Huys, and J. Swings. 2001. Applicability of rep-PCR fingerprinting for identification of Lactobacillus species. FEMS Microbiol. Lett. 205:31-36.

Gobbetti, M., B. Folkertsma, P. F. Fox, A. Corsetti, E. Smacchi, M. De Angelis, J. Rossi, K. Kilcawley, and M. Cortini. 1999. Microbiology and biochemistry of Fossa (pit) cheese. Int. Dairy J. 9:763-773.

Goncu, A., and Z. Alpkent. 2005. Sensory and chemical properties of white pickled cheese produced using kefir, yogurt or a commercial cheese culture as a starter. Int. Dairy J. 15:771-776.

Hayaloğlu, A. A. 2007. Comparisons of different single-strain starter cultures for their effects on ripening and grading of Beyaz cheese. Int. J. Food Sci. Technol. 42:930-938.

Hayaloğlu, A. A., M. Güven, and P. F. Fox. 2002. Microbiological, biochemical and technological properties of Turkish White cheese "Beyaz peynir." . Int. Dairy J. 12:635-648.

Hayaloğlu, A. A., M. Guven, P. F. Fox, J. A. Hannon, and P. L. H. McSweeney. 2004. Proteolysis in Turkish White-brined cheese made with defined strains of Lactococcus. Int. Dairy J. 14:599-610.

Hayaloğlu, A. A., M. Guven, P. F. Fox, and P. L. H. McSweeney 2005. Influence of starters on chemical, biochemical, and sensory changes in Turkish White-brined cheese during ripening. J. Dairy Sci. 88:3460-3474

Kandler, O., and N. Weiss. 1986. Genus Lactobacillus. Pages 12091234 in Bergey's Manual of Systematic Bacteriology. Vol. 2. P. H. A. Sneath, N. S. Mair, M. E. Sharpe, and J. G. Holt, ed. Williams \& Wilkins, Baltimore, MD.

Karahan, A. G., B. Arıdoğan-Cicioğlu, and M. L. Çakmakçı. 2002. Genel Mikrobiyoloji Uygulama Kılavuzu. SDU, Isparta, Turkey.

Karakuş, M., and I. Alperden. 1995. Effect of starter composed of various species of lactic acid bacteria on quality and ripening of Turkish white pickled cheese. LWT_Food Sci. Technol. 28:404409
Karakuş, M., M. Borcakli, and I. Alperden. 1992. Beyaz peynirin olgunlasmasi sürecinde laktik asit bakterileri. Gida 17:363-369.

Katsiari, M. C., L. P. Voutsinas, and E. Kondly. 2002. Improvement of sensory quality of low-fat Kefalograviera-type cheese with commercial adjunct cultures. Int. Dairy J. 12:757-764.

Kayagil, F. 2006. Effect of traditional starter cultures on quality of cheese. MSc thesis, The Graduate School of Natural and Applied Sciences, Middle East Technical University, Ankara, Turkey.

Kesenkas, H., and N. Akbulut. 2006. The effects of some adjunct yeast cultures on the aroma compounds of White cheese. Ege Universitesi Ziraat Fakultesi Dergisi 43:73-84.

Kunene, N. F., I. Geornaras, A. Von Holy, and J. W. Hastings. 2000. Characterization and determination of origin of lactic acid bacteria from a sorghum-based fermented weaning food by analysis of soluble proteins and amplified fragment length polymorphism fingerprinting. Appl. Environ. Microbiol. 66:1084-1092.

Laemmli, U. K. 1970. Cleavage of structural proteins during the assembly of the head of bacteriophage T4. Nature 227:680-685.

McSweeney, P. L. H., P. F. Fox, J. A. Lucey, K. N. Jordan, and T. M. Cogan. 1993. Contribution of the indigenous microflora to the maturation of Cheddar cheese. Int. Dairy J. 3:631-634.

McSweeney, P. L. H., E. M. Walsh, P. F. Fox, T. M. Cogan, F. D. Drinan, and M. Castelo-Gonzalez. 1994. A procedure for the manufacture of Cheddar cheese under controlled bacteriological conditions and the effect of adjunct lactobacilli on cheese quality. Ir. J. Agric. Food Res. 33:183-192.

Oner, Z., A. G. Karahan, and H. Aloglu. 2006a. Changes in the microbiological and chemical characteristics of an artisanal Turkish White cheese during ripening. LWT-Food Sci. Technol. $39: 449-454$.

Öner, Z., A. G. Karahan, H. Sanlıdere, G. Kılıç, and A. Gündoğdu. 2006b. Selection of starter culture for Beyaz cheese. Page 46 in Proc. 1st International Egyptian-Jordanian Conference on Biotechnology and Sustainable Development: Current Status and Future Scenarios. Dec. 11-14, 2006. National Research Center, Cairo, Egypt.

Ong, L., A. Henriksson, and N. P. Shah. 2006. Development of probiotic Cheddar cheese containing Lactobacillus acidophilus, Lb. casei, Lb. paracasei and Bifidobacterium spp. and the influence of these bacteria on proteolytic patterns and production of organic acid. Int. Dairy J. 16:446-456.

Peterson, S. D., and R. T. Marshall. 1990. Nonstarter lactobacilli in Cheddar cheese: A review. J. Dairy Sci. 73:1395-1410.

Poveda, J. M., M. J. Sousa, L. Cabezas, and P. L. H. Mcsweeney. 2003. Preliminary observations on proteolysis in Manchego cheese made with a defined-strain starter culture and adjunct starter (Lactobacillus plantarum) or a commercial starter. Int. Dairy J. 13:169-178

Shakeel-Ur-Rehman, A. H. Pripp, P. L. H. McSweeney, and P. F. Fox. 1999. Assessing the proteolytic and cheese ripening properties of single strains of Lactococcus in miniature cheeses. Lait 79:361383.

Tarakçı, Z., and Y. Tuncturk. 2008. The effect of adjunct cultures on some chemical and biochemical properties of white-brined cheese. J. Food Biochem. 32:490-505.

Topçu, A. 2004. Kaşar ve Beyaz peynirlerde acılaşmaya yol açan peptidlerin saptanması ve acılaşmada depolama koşulları ile starter kültürlerin etkisinin incelenmesi. Hacettepe Üniversitesi Fen Bilimleri Enstitüsü Doktora Tezi, Ankara, Turkey.

Trujillo, A. J., M. Capellas, J. Saldo, R. Gervilla, and B. Guamis 2002. Applications of high- hydrostatic pressure on milk and dairy products: A review. Innov. Food Sci. Emerg. Technol. 3/4:295307.

TS. 1978. TS 3046 Peynirde yă miktarı (Van Gulik Yöntemi) Tayini Standardı. The Institute of Turkish Standards, Ankara, Turkey.

TS. 1986. TS 4708 Peynir ve Eritme Peynir Ürünleri, Klorür Miktarı Tayini, Potansiyometrik titrasyon metodu. The Institute of Turkish Standards, Ankara, Turkey.

TS. 1995. TS 591 Beyaz Peynir. The Institute of Turkish Standards, Ankara, Turkey. 
Tuncturk, Y., Z. Tarakci, and H. Durmaz. 2008. Effect of starter cultures on the chemical and lipolytic content, nitrogen fraction and casein degradation of White-brined cheese. Arch. Lebensmittelhyg. 59:27-33.

Tzanetakis, N., and E. Litopoulou-Tzanetaki. 1992. Changes in numbers and kinds of lactic acid bacteria in Feta and Teleme, two Greek cheeses from ewes' milk. J. Dairy Sci. 75:1389-1393.

Tzanetakis, N., A. Vafopoulou-Mastrojiannaki, and E. LitopoulouTzanetaki. 1995. The quality of white-brined cheese from goat's milk made with different starters. Food Microbiol. 12:55-63.
Ventura, M., and R. Zink. 2002. Specific identification and molecular typing analysis of Lactobacillus johnsonii by using PCR-based methods and pulsed-field gel electrophoresis. FEMS Microbiol. Lett. 217:141-154.

Yetişmeyen, A. 1995. Süt Teknolojisi. Ankara Üniversitesi Yayınları. Ankara, Turkey.

Yılsay, T. 2000. Lipaz kullanımının Mihaliç peynirinin olgunlaşma süresine etkisi. Doktora Tezi, Uludağ Üniversitesi FBE Gıda Mühendisliği Anabilim Dalı, Bursa, Turkey. 